DOI: $10.22616 /$ REEP.2020.020

\title{
Problem-Solving - a Key Precondition for Learning Mathematics at Pre-School
}

\author{
Dagnija Vigule Dr.paed. \\ University of Latvia, Latvia \\ dagnija.vigule@lu.lv
}

\begin{abstract}
Conventional education provides for a specific division of training subjects, execution of curriculum, and definite information to be acquired - things to be learned and remembered. This leads to a wrong impression that mathematics at pre-school covers only activities with digits, summing, subtraction, learning sizes and forms. However, mathematics is something more than just a specific knowledge. It is a set of various abilities and skills. The research is aimed at theoretical revealing of as a significant requirement for learning mathematics at pre-school and to work out the scheme of formation of mathematical notions of pre-schoolers. Development of a pre-schooler is influenced both by what is thought and by how it is thought. It is worth remembering that the child can learn mathematics by doing handicrafts, moulding, drawing, building sandcastles, taking care of a planted onion. Logically, mathematical skills or reasoning skills are acquired through real objects in the surrounding environment. When solving problem situations, child is engaged in decision-making process and thus not only gets valuable practical experience in solving problems, but also gets teacher's approval for the ability to make decisions. Children who in their childhood have gained experience in not stepping back in case of a failure, the ones who have learned to look critically at a problem and solve it, have learned to learn.
\end{abstract}

Keywords: pre-schooler, mathematics, problem situation, pre-school education.

\section{Introduction}

The article has been intended as a theoretical insight into the problems related to the formation of mathematical notions of pre-schoolers arising when conventional education system and conventional attitude towards learning techniques meet new forms of education requiring "modification of the training process focus" (Buzan, 2011, 30). Conventional or formal education provides for a certain division of training subjects, execution of the curriculum and specific information to be acquired - things that should be learned and remembered. This leads to a wrong impression that mathematics at a pre-school is only activities with digits, summing, subtraction, learning sizes and forms. The child is ready for basic education if he/she can fill in the task sheet. However, mathematics is something more than just a specific knowledge. It is a set of various abilities and skills. To analyse how the new educational content and approach to teaching will change math learning in preschool, it is important to explore previous rules. Regulation on the state pre-school education guidelines of 2012 also introduces not only the expected pre-school education outcomes in mathematics as the child reaches the school age, but also the skills to be developed. Cognitive activity, curiosity, understanding of logical sequences of activities, skills to reason one's opinion, observe and ask questions is what shall be promoted at pre-school age (Noteikumi par valsts..., 2012). Practical observations show that at pre-school more attention is devoted to knowing certain facts, whereas learning of the above skills is left behind.

Teacher - driven and teacher-centred learning at pre-school, vertical relevance (Katz, Chard, Kogan, 2014) which is based on pre-developed plans and materials, do not provide children with the foundations necessary for academic success in future, do not help children to live in a constantly changing world, as children do not have an opportunity to learn needed knowledge, skills and attitudes by themselves. Thus, understanding of what mathematics is as well as the attitude towards the process of - teaching and learning it - and subsequently the attitude towards the child shall be changed.

For pre-schoolers, mathematics is a way to learn about the world, solve problems and build their own experience. At first, the child meets mathematics indirectly, in different everyday situations. By manipulating, being active and playing with objects the child learns about their characteristics, mutual relations and makes their own discoveries. By finding correlations between their own activities and phenomena of the surrounding environment, the child sees the meaning of the world, and the development of his/her thinking is initiated. The key challenge to a pre-school teacher in the process of teaching mathematics lies in facilitation of the inborn mathematical thinking skills (Geist, 2009; Pound, 
2008), maintaining child's interest, enthusiasm and curiosity. The pedagogue shall organise teaching and learning process in a way to ensure that children find mathematics interesting (Brewer, 2007). When learning mathematics, the pedagogue should bear in mind that only the things the child has found out are important and have sustainable value. When children are acting on their own initiative, using objects that seem topical and interesting to them, they are more interested in the learning process, and the new knowledge is preserved in their memory better. Children understand and remember experiences better when they have opportunity to research and be engaged practically. Each child learns new things at his/her own pace, therefore pedagogues shall take care to ensure that the child has time and opportunities to engage in activities with new materials or games that have seemed to be interesting until the child has acquired all new skills. Children need time to develop understanding of abstract mathematical ideas (Robertson, 2017). The most valuable learning activity organized by pedagogues is when the child engages in activity and does not even realize that learning is taking place. It is of a major importance that the child can continue the activity without direct guidance or intervention of a teacher.

The study of the pre-school curriculum 2018 developed by the National Centre for Education as a support material for pedagogues implementing the Regulation No 716 "Regulations on State Guidelines for PreSchool Education and Models of Pre-School Education Programme" of the Cabinet of Ministry of 21 November 2018 (Noteikumi par valsts..., 2018) shows significant differences from the previous programme. The curriculum includes both outcomes of learning and transversal skills, as well as points out the habits and virtues to be developed and facilitated at pre-school. The outcomes planned in mathematics, unlike in the previous curriculum, are grouped into three content units (Figure 1).
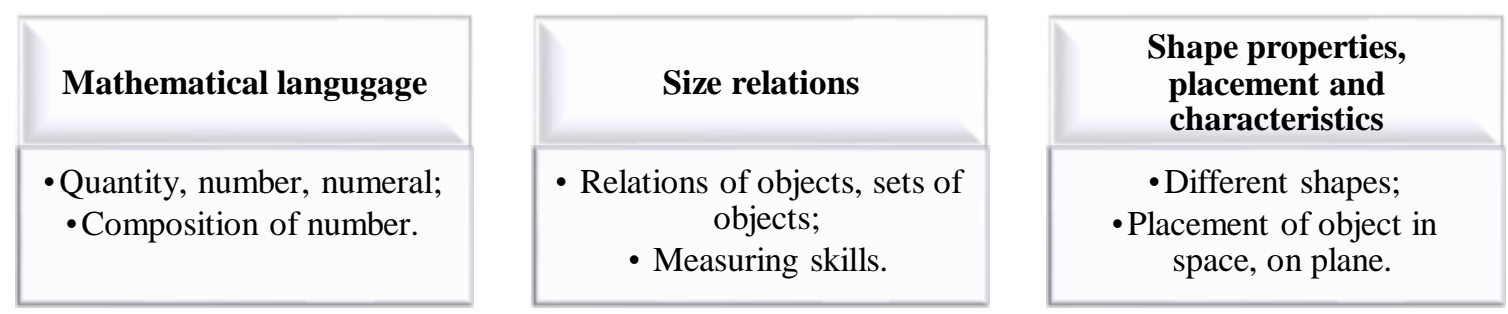

Figure 1. Content units of mathematics curriculum at pre-school.

Domain mathematics is closely related to the transversal skill of critical thinking and problem-solving. It means that the child at the pre-school age should learn also other skills apart from the contents under the curriculum of mathematics. Scientists (Brewer, 2007; Geist, 2009; Bullard, 2017; Cotton, 2019) in their researches point out the importance of pre-school teachers basing their work on the content standards and process standards. Content standards give pedagogues information about the knowledge and skills to be learned at a certain age, e.g., learning numbers, counting, geometry. "The process standards include problem solving, reasoning and proof, communication, connections, and representation" (Geist, 2009, 16). Mathematics is not only a series of facts, isolated skills, it is a sequence of relations, notions and thinking processes, a structure of mutually related notions and sequential activities (Fisher, 2005). The curriculum provides for the development of skills like problem-solving, reasoning, communication, making comparisons, and argumentation. "The process of finding information, analysing data, and reaching conclusion is considered more important than learning facts" (Brewer, 2007, 59). These skills are both developed when acquiring mathematics and help in learning and understanding mathematical notions. At the same time, these habitual skills are necessary throughout the whole life since they contribute to achievements in all fields of life.

Pre-schoolers have a natural desire to overcome obstacles hindering solution, i.e., to solve problem situations faced (Minetola, Ziegenfuss, Chrisman, 2014; Geist, 2009; Fisher, 2005; Tucker, 2014). Problem situations occur when child is willing to find a solution for the current situation, i.e., moment when he/she wants to understand something (Gabova, 2014). Solving problems is a certain form of cognitive processing (Fisher, 2005). Child has to see a problem to solve it, think of a plan, implement the plan and then see if the plan worked (Bullard, 2017; Copley, 2010; Epstein, 2014). Problem situations are solved gradually (Figure 2).

When engaging in problem-solving, the child:

- experiences problem-solving process from the beginning to the end; 
- updates their own knowledge, analyses, sees regularities;

- develops skills necessary for each step of the problem-solving.

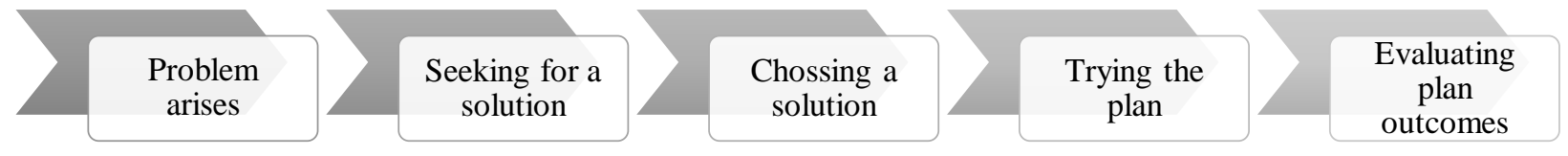

Figure 2. Problem-solving steps (Bullard, 2017).

By observing problem-solving process pedagogues ask exhilarating questions not only to find out how child deals with the problem, but cognizes as a child:

- learns;

- uses acquired knowledge and facts to solve the problem;

- controls emotions;

- makes contact.

The practice shows that pre-schoolers lack experience in problem-solving, they struggle to define a problem, analyse ways to solve it, as well as to reflect on it. Ability to solve problematic situation often is reduced by the teacher's attitude. Child is expected to give one, correct answer. The wrong answer is corrected or rejected directly. Children are not given time to think about the problematic situation. Unlike in the theory, in practice mistakes are not perceived as an important part of the learning process that begins discussion and encourages thinking process. By learning mathematics at pre-school, more attention should be devoted to solving of problematic situations.

The research is aimed at theoretical revealing of as a significant requirement for learning mathematics at pre-school and to work out the scheme of formation of mathematical notions of pre-schoolers.

\section{Methodology}

The study is an on theoretical research - the analysis of literature and documents. The tasks of the research are to analyse scientific literature on teaching mathematics in pre - school, to reflection of author' pedagogical experience, to work out the scheme of formation of mathematical notions of pre-schoolers. The research covers the analysis of pre-school education guidelines (Noteikumi par valsts..., 2018) developed by the National Centre for Education within the framework of the project "Competence-Based Approach to Curriculum," pre-school curriculum (Pirmsskolas mācību programma..., 2019) and document Education for modern literacy: description of the teaching/learning content and approach (Skola 2030..., 2017) giving particular attention to thinking and problem-solving skills to be acquired at pre-school. Theoretical approaches are based on the following scientific findings about child-centered learning (Geist, 2009; Brewer, 2007; Katz, Chard, Kogan, 2014; Epstein, 2014), the formation of mathematical notions of pre-schoolers (Copley, 2010; Taylor, Harris, 2014; Chigeza, Sorin, 2016; Helmane, 2017; Robertson, 2017; Cotton, 2019), and problem-solving in pre-school (Fisher, 2005; Greenwood et al., 2006; Geist, 2009; Hughes, 2009; Kostelnik et al., 2014; Haylock, Cockburn, 2017; Bullard, 2017).

The research methods used in the article: 1) study, analysis and evaluation of scientific literature in the field of teaching mathematics in pre-school;2) reflection of author' pedagogical experience.

\section{Results and Discussion}

Along with the placement of child and his/her ideas (defined by the "Regulations on State Guidelines for Pre-School Education and Models of Pre-School Education Programme") in the centre of learning process, vertical relevance loses its topicality. This approach covers only learning of mathematics arranged in a definite order. All needed ideas shall be given to children in a certain sequence. Assuming mathematics consists of chain-linked notions and the following ideas cannot be understood if the previous link is missing, the pedagogue focuses on implementation of the training programme, as the results can be achieved only when all steps are taken in the right order. For this reason, pedagogues like to use pre-developed materials that not always reflect the real life, interests of a child, but prepare children to perform tasks with increasing difficulty. The tasks in workbooks and accomplishment thereof help children to reach the next level, yet they do not show how new skills can be used in everyday life, "textbooks should never be the sole basic for 
learning any subject at any age" (Geist, 2009, 110). Practice shows that work with the task sheets allows children to learn how to link count and number, write numbers in a right sequence. However, children in a real-life find it difficult to tell what is more and less when they are comparing sets of objects and answering questions. Scientists (Haylock, Cockburn, 2017; Robertson, 2017; Montague-Smith et al., 2018; Geist, 2009; Copley, 2010) also point out that children face difficulties when speaking about comparisons as well as using more and less. It shows that child has learned facts but does not understand the essence of the sequence of numbers and the fact that sequence of numbers is set and invariable. Moreover, on a daily basis, mathematics does not hide in isolated activities, skills, or in a separate list of knowledge and facts. Knowledge and remembering of facts $(2+2=4)$, the ability to answer in a pre-ready form (What operation is this? This is ...) do not help children in real life, do not help in understanding mathematics as a strictly structured network of ideas (Fisher, 2005). Direct teaching, passive accumulation of knowledge in case when child is only repeating, and imitating actions of adults contradicts the things child is learning. Child is learning trough acting, manipulating objects and thinking over the results. Too early acquisition of formal contents of mathematics, manipulation of abstract notions and symbols endangers both academic growth of a child and social, emotional development (Hughes, 2009; Geist, 2009).

Scientists (Fisher, 2005; Geist, 2009) believe that the formation of mathematical apprehensions and skills is not only related to certain knowledge and skills but also to the development of the brain activity, solving of problem situations. Teaching mathematics to a pre-schooler is not only a transfer of specific knowledge or techniques used to solve tasks, but also formation of psychological mechanisms that ensure successful development, independence in further learning and practical application of the mathematical knowledge acquired (Gabova, 2014; Taylor, Harris, 2014). The main task hides in activating and facilitating development of child's thinking: ability to reason, find cause-effect relationships, understand regularities of the surrounding world. Pre-school is where empirical generalization takes place-children are generalizing what they have experienced, what helps them in forming their sensory skills, what is processed by intellectual abilities. Logically, mathematical skills or reasoning skills are acquired through real objects in the surrounding environment.

Development of a pre-schooler is influenced both by what is thought and by how it is thought. The horizontal relevance (Katz, Chard, Kogan, 2014) does not provide for remembering of facts and rules, for solving of artificial and clearly defined problematic situations with one correct answer instead of practical solving of problems related to child's experience and interests that arise in everyday life or created by a pedagogue based on the child's interests. It is worth remembering that the child can learn mathematics by doing handicrafts, moulding, drawing, building sandcastles, taking care of the planted onion. When an adult sees the presence of mathematics in everyday life, it is easy to integrate it into any activity and any field of study. However, adults seeing chances to learn mathematical concepts and regularities via playing and other activities is not enough. Pre-schoolers gain deep and persistent understanding of mathematical relationships by seeing the meaning of what is learned and having ability to apply it in everyday life. Such a view of the problem does not diminish the role of an adult in teaching and learning but changes his perception of both pre-schoolers and the way of learning mathematics (Helmane, 2017; Kostelnik et al., 2014).

Document "School 2030. Education for Modern Literacy: Description of the Teaching/Learning Content and Approach" shows the necessity to improve both learning content and approach. It states that children can solve tasks that are related to remembering facts, acting based on known algorithm in known situations, but finds it difficult to solve non-standard situations, link theoretical knowledge with the real life (Skola 2030 ..., 2017). Significance of meaningful studies by learning mathematics and ability to use the known is discussed by the scientists (Haylock, Cockburn, 2017; Brewer, 2007; Geist, 2009; Kostelnik et al., 2014) by pointing out that both researches and practice show that understanding-based learning gives more durable knowledge, psychological satisfaction and ensures practical use of knowledge better than repetition-based knowledge.

Meaningful learning, use of understanding in the studies becomes challenges to the pre-school practices. Teacher-child relationships within the learning process as well as learning environment should be changed. Figure 3 has been based on the analysis of the researches (Brewer, 2007; Geist, 2009). It shows the most significant differences between traditional (indicated with grey) and child-centred training process. Three important components of the learning process-child, pedagogue, and environment-were compared by indicating the changes needed in the Latvian pre-school education. 
In child-centred learning, acquisition of mathematical concepts at pre-school age shall be based on individual willingness to engage in an activity, self-develop. E. Geist (2009) believes that large part of problems related to learning mathematics at pre-school may be solved if child's interest in the issue discussed during the play lesson would continue. Due to this reason, in planning lessons of mathematics an adult should note the balance between what is provided for in the programme and individual interests of a child. Pedagogues should be flexible in the choice of both curriculum and learning aids and:

- take into account development regularities at a certain age;

- know abilities as well as strengths and weaknesses of each child;

- be aware that any child is a pragmatist who considers his/her best interests first.

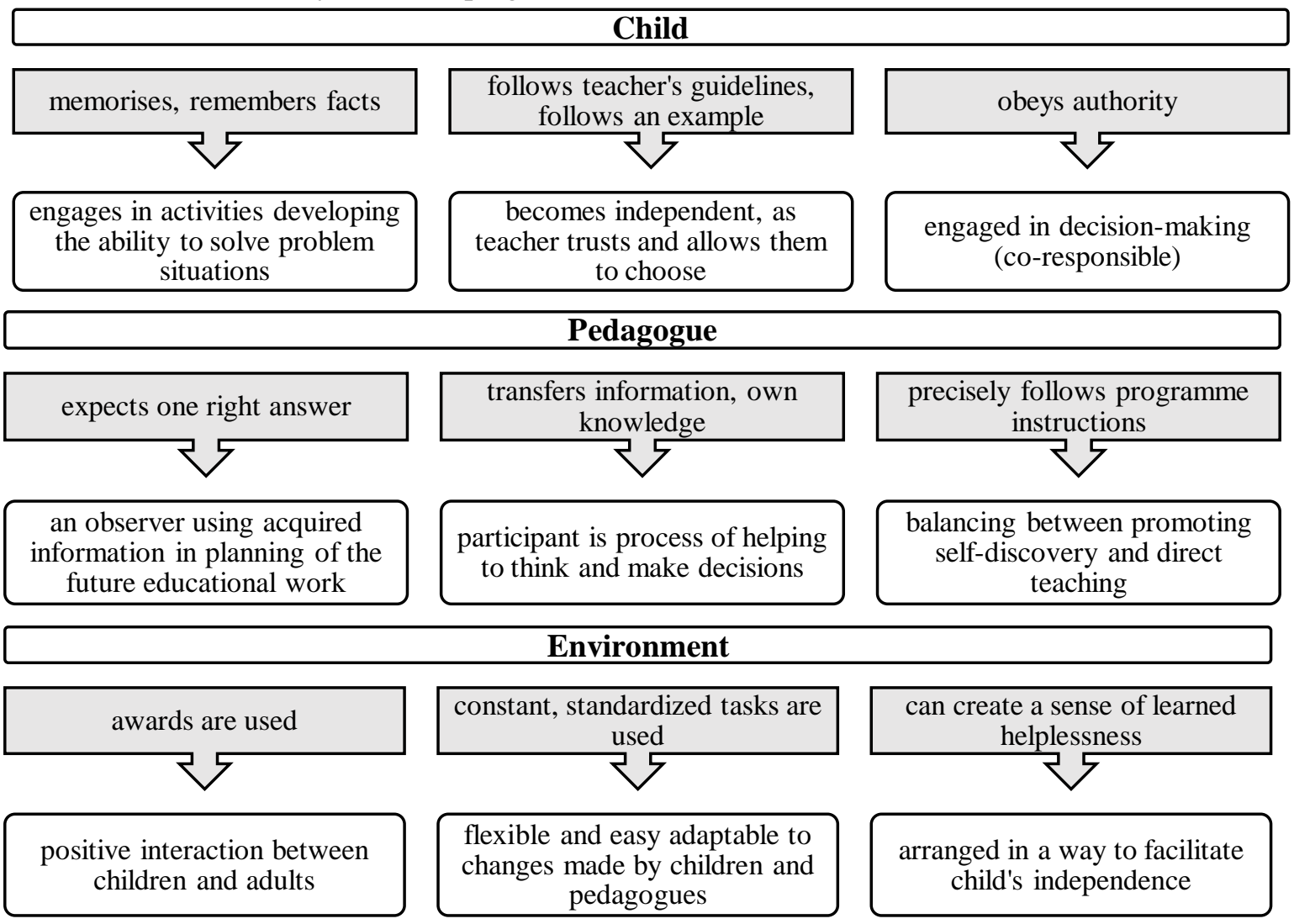

Figure 3. Comparison of child-centred and traditional components in learning process

(Brewer, 2007; Geist, 2009).

Pre-schoolers learn mathematics by manipulating objects and finding out their relationships studying, experimenting, making mistakes (Brewer, 2007; Kostelnik et al., 2014). The process of action is where mathematical problem-solving and thinking skills are formed and developed. Each child is a unique individual having their own skills and interests. The pedagogue should remember that the child thinks about things that seem interesting to him/her. It means that a pre-school teacher should seek for and offer problem situations suitable to child's age, interests and experiences, and indirectly encourage the child to seek the answer. A learning problem is topical if it is a problem in child's opinion. Only if child has chosen to take part in solving the problem by himself, teaching and learning can take place naturally and efficiently.

Problem situation arises from controversy, question, surprise or misunderstanding, and it is the beginning of thinking. "Problem solving also provides much of the purpose for other cognitive processes such as perception, language, memory, and conceptual understanding" (Siegler, Alibali, 2005, 341). A. Vorobjov (2000) also refers to the arising of a problem situation as the beginning of the thinking process. The problem situation itself encourages the child to solve it, and the child has to start think about what he/she could do to solve the problem or situation. In respect to the arising of problem situations encouraging thinking processes, A. Vorobjovs (2000) points out the necessity for three pre-conditions simultaneously (Figure 4). 
Learning activities in mathematics should be drawn up based on the child's natural ability to reason and solve problems (Geist, 2009). Child's learning is based on a play and solving of problem situations, and the best if problem situations are involved in a play (Chigeza, Sorin, 2016; Moomaw, 2013; Gabova, 2014). M.A. Gabova (2014) mentions a separate method-a problem method which is based on a teacher-created problem situation noting child's experience, thus ensuring that child can solve the problem on its own. By solving problem situations that has risen, the child is playing and experiencing a storyline offered by the teacher together with the main characters trough active cognitive action and in neutral atmosphere. The support given by the pedagogue is indirect. The chid is asked open-ended questions, his/her interest is maintained, and the principles of problem solving are observed:

- mathematic is thinking and not learning the right answers;

- process is more important than the result,

- the answer to the question is logically sequential and not given by the teacher (Geist, 2009).

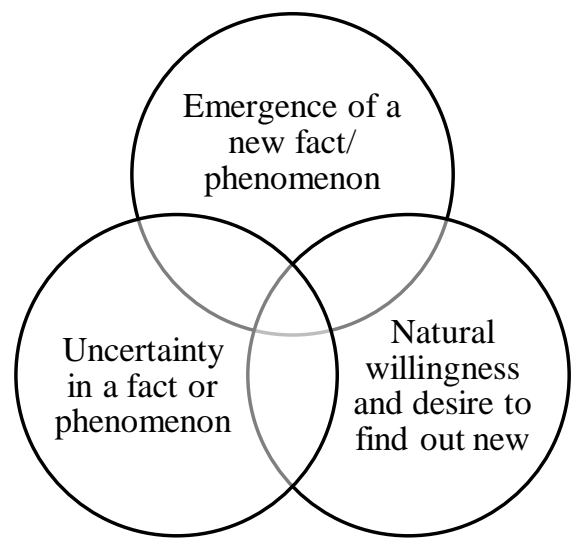

Figure 4. Pre-conditions for problem situation to arise (Vorobjovs, 2000).

Thinking about a problem is important as or even more important than finding the answer or solution. If the child is used to a teacher knowing all the answers, he/she relies on own thinking abilities increasingly less. If the pedagogue does not give the child an opportunity to think and solve problem situation by himself/herself, the child also does not show initiative in doing that. The child quickly understands what is expected from him and is able to adjust. When given the opportunity to find the right answers on his/her own, the child discovers that he can find mistakes within the thinking process quite well. The child has to understand that the right answer does not come from the teacher or book, but it does come from logical conclusions. The pedagogue both initiates and maintains the discussion by asking open-ended questions, encouraging attempts, research, and discovery. The pedagogue accompanies the child and engages un his/her activity when necessary or is asked by a child. Along with the experience gained via discussions, trying and making mistakes, child starts to understand that the right answer is not given by the teacher or book, but it comes as a logical conclusion made based on the own activity.

By working practically, using the knowledge acquired, engaging in a discussion, the child gains experience, gradually building confidence in the own abilities (Bullard, 2017), becomes aware of the own role in solving problem situations and starts expressing activity directed towards achieving a result. Researchers (Greenwood et al., 2006) believe that children who in their childhood have gained experience in not stepping back in case of a failure, the ones who have learned to look critically at a problem and solve it, have learned to learn. Timely development of cognitive skills-ability to solve problems, find necessary information, affect child's further success both at school and in life. Based on the above-mentioned analysis of scientific literature and personal pedagogical experience, the author has developed the scheme of formation of mathematical notions of pre-schoolers (Figure 5). 


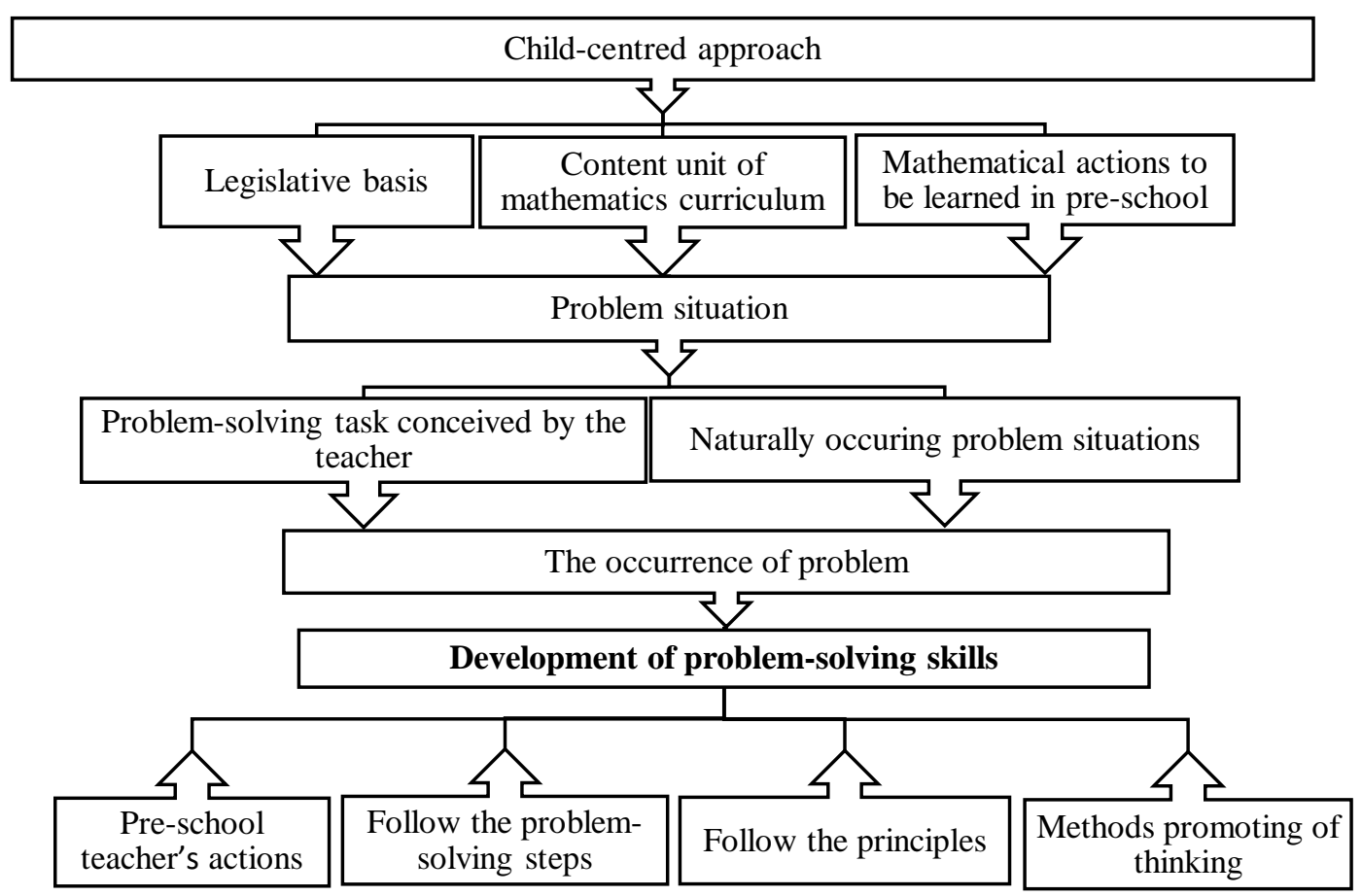

Figure 5. The scheme of formation of mathematical notions of pre-schoolers.

The Figure 5 contains a logical framework for the pre-schoolers' mathematical understanding, including both the content, and the emergence of problem situations, and the set of measures needed to develop pre-schoolers' problem-solving abilities.

\section{Conclusions}

When learning mathematics at pre-school, an ability to solve problem situations has to be facilitated, as it also is a part of the mathematics content. At pre-school, mathematics should be thought by observing a balance between the curriculum and child's interests as well as child's natural ability to reason and solve problem situations. In solving problem situations, the result has less importance than the thinking and solving process itself. Support given by the pedagogue is indirect. By acting, trying, experimenting, making mistakes, correcting mistakes, talking to the teacher, reflecting on what they do, child begins to realize himself/herself as a personality that can influence the world. Moreover, when solving problem situations, child is engaged in decision-making, he/she is trusted and is co-responsible for the decision made. What type of blocks should be used to ensure that the tower does not fall apart, what type should be used for big and what type for small houses? At pre-school, decision-making starts with options, initially a choice between two options. In such a way, child not only gets valuable practical experience in solving problems, but also gets approval for his/her abilities to make decisions, which is schematically depicted in Figure 5 by the author.

\section{Bibliography}

1. Brewer J.A. (2007). Introduction to Early Childhood Education: Preschool Through Primary Grades (6 ${ }^{\text {th }}$ ed.). Boston, Massachusetts: Pearson Education.

2. Bullard J. (2017). Creating Environments for Learning: Birth to Age Eight (3 ${ }^{\text {rd }}$ ed.). Cambridge: Pearson Education.

3. Buzan T. (2011). Buzan's Study Skills: Mind Maps, Memory Techniques, Speed Reading. Harlow: BBC Active.

4. Chigeza P., Sorin R. (2016). Kindergarten Children Demonstrating Numeracy Concepts through Drawings and Explanations: Intentional Teaching within Play-based Learning. Australian Journal of Teacher Education, 41(5), 65-77. Retrieved from https://files.eric.ed.gov/fulltext/EJ1102066.pdf

5. Copley J.V. (2010). The Young Child and Mathematics ( $2^{\text {nd }}$ ed.). Washington: NAEYC. 
6. Cotton T. (2019). How to Develop Confident Mathematicians in the Early Years: A Guide for Practitioners and Parents. New York: Routledge.

7. Epstein A.S. (2014). The Intentional Teacher: Choosing the Best Strategies for Young Children 's Learning. Washington: National Association for the Education of Young Children.

8. Fisher R. (2005). Teaching Children to Think ( $2^{\text {nd }}$ ed.). Cheltenham: Nelson Thornes.

9. Gabova M.A. (2014). Matematicheskoye razvitiye detey doshkol'nogo vozrasta: teoriya i tekhnologii [Mathematical development of pre-schoolers: theory and methodologies]. Moskva: Direkt-Media. (in Russian)

10. Geist E. (2009). Children Are Born Mathematicians: Supporting Mathematical Development, Birth to Age, 8. Upper Saddle River, N.J.: Merrill/Pearson.

11. Greenwood Ch.R., Walker D., Carta J.J., Higgins S.K. (2006). Developing a general outcome measure of growth in the cognitive abilities of children 1 to 4 years old: The Early ProblemSolving Indicator. School Psychology Review, 35(4), 535-551. Retrieved from https://www.quest ia.com/library/journal/1 G1-158306969/developing-a-general-outcome-measure-of-growth-in

12. Haylock D., Cockburn A.D. (2017). Understanding mathematics for young children: A guide for teachers of children 3-7 ( $5^{\text {th }}$ ed.). London: SAGE Publications.

13. Helmane I. (2017). Thematic Approach and Mathematics Textbooks in Primary School. In V. Dislere (Ed.), The Proceedings of the International Scientific Conference Rural Environment. Education. Personality. (REEP), 10. Jelgava: LLU, 70- 77. Retrieved from https://lufb.llu.lv/conference/REEP/2017/Latvia-Univ-Agricult-REEP-2017_proceedings-70-77.pdf

14. Hughes A.M. (2009). Problem solving, reasoning and numeracy in the early years foundation stage. London and New York: Routledge.

15. Katz L.G., Chard S.C., Kogan Y. (2014). Engaging children's minds: The project approach ( $3^{\text {rd }}$ ed.). Santa Barbara, California: Praeger.

16. Kostelnik M.J., Rupiper M.L., Soderman A.K., Whiren A.P. (2014). Developmentally Appropriate Curriculum in Action. Upper Saddle River, N.J.: Pearson.

17. Minetola J.R., Ziegenfuss R.G., Chrisman J.K. (2014). Teaching Young Children Mathematics. New York: Routledge.

18. Montague-Smith A., Cotton T., Hansen A., Price A.J. (2018). Mathematics in Early Years Education (4 ${ }^{\text {th }}$ ed.). London and New York: Routledge.

19. Moomaw S. (2013). Teaching STEM in the Early Years: Activities for Integrating Science, Technology, Engineering, and Mathematics. St. Paul: Redleaf Press.

20. Noteikumi par valsts pirmsskolas izglìtības vadlīnijām [Rules on national pre-primary education guidelines]. (2012). Retrieved from https://likumi.lv/ta/id/250854 (in Latvian)

21. Noteikumi par valsts pirmsskolas izglìtības vadlīnijām un pirmsskolas izglītības programmu paraugiem [Regulations Regarding Guidelines for State Pre-School Education and Samples of PreSchool Education Programmes]. (2018). Retrieved from https://likumi.lv/ta/id/303371 (in Latvian)

22. Pirmsskolas mācību programma [Preschool curriculum]. (2019). Skola 2030. Rīga: VISC Retrieved from https://mape.skola2030.lv/resources/10 (in Latvian)

23. Pound L. (2008). Thinking and Learning About Mathematics in the Early Years. New York: Routledge.

24. Robertson J. (2017). Messy maths: A playful, outdoor approach for early years. Carmarthen: Independent Thinking Press.

25. Siegler R.S., Alibali M.W. (2005). Children's Thinking ( $4^{\text {th }}$ ed.). Upper Saddle River: Pearson Prentice Hall.

26. Skola 2030. Izglìtība mūsdienīgai lietpratībai: mācību satura un pieejas apraksts [School 2030. Education for modern literacy: description of the teaching/learning content and approach]. (2017). Rìga: VISC. Retrieved from http://www.izm.gov.lv/images/aktualitates/2017/Skola2030Dokuments.pdf (in Latvian)

27. Taylor H., Harris A. (Eds.). (2014). Learning and Teaching Mathematics 0-8. London: SAGE Publications. doi: 10.4135/9781526401601

28. Tucker K. (2014). Mathematics Through play in the early years ( $3^{\text {rd }}$ ed.). London: SAGE Publications.

29. Vorobjovs A. (2000). Vispārīgā psiholoǵija [General psychology]. Rīga: Izglìtīibas soḷi. (in Latvian) 